\title{
SMALL-SCALE TERRACES AND ISOLATED RIMSTONE POOLS ON STALAGMITES IN CAVES EXHIBIT STRIKING SIMILARITY TO LARGE-SCALE TERRACE LANDSCAPES AT HOT SPRINGS
}

\author{
DROBNE SIGASTE TERASE NA STALAGMITIH SO \\ PRESENETLJIVO PODOBNE VELIKIM TERASAM, KI RASTEJO \\ OB TERMALNIH KRAŠKIH IZVIRIH
}

\author{
Wolfgang DREYBRODT ${ }^{1,2} \&$ Franci GABROVŠEK ${ }^{2}$
}

\begin{abstract}
UDC 911.2:551.435.843

Wolfgang Dreybrodt \& Franci Gabrovšek: Small-scale terraces and isolated rimstone pools on stalagmites in caves exhibit striking similarity to large-scale terrace landscapes at hot springs

We report on sinter terrace forms on the centimetre scale observed on the top and at the base of a stalagmite in Škocjanske jame (Škocjan caves). These exhibit connected rimstone dams, forming a net-like pattern with active water pools inside. The form is similar to those seen at the large travertine terraces, which form by precipitation of calcite from spring waters highly supersaturated with respect to calcite. In contrast to these patterns we have also found isolated sinter basins with dimensions of a few centimeter on stalagmite-like structures in the cave Dimnice, Slovenia. Similar basins a few meters wide are a tourist attraction in Pamukkale, Denizli, Turkey. The observed features have grown from supersaturated solutions of calcium carbonate in laminar flow. Large-scale landscapes originate under conditions of turbulent flow. Some ideas are presented why, in spite of the clear difference in flow, the shapes are similar on all scales.

Keywords: Rimstone pools, precipitation, Škocjanske jame (Škocjan caves), Dimnice.
\end{abstract}

Izvleček: $\quad$ UDK 911.2:551.435.843 Wolfgang Dreybrodt \& Franci Gabrovšek: Drobne sigaste terase na stalagmitih so presenetljivo podobne velikim terasam, ki rastejo ob termalnih kraških izvirih

$\mathrm{V}$ prispevku poročamo o sigastih terasah reda velikosti centimetra, ki smo jih opazili na stalagmitu v Škocjanskih jamah. Pregrade drobnih sigovih ponvic tvorijo mrežo teras, ki močno spominja na terase $\mathrm{v}$ velikem merilu, kot jih najdemo na mestih, kjer se kalcit izloča iz visoko prenasičenih vod termalnih izvirov. Precej drugačne, izolirane sigove ponvice velikosti nekaj centimetrov, pa smo našli na stalagmitih v jami Dimnice. Podobne ponvice $\mathrm{v}$ velikem merilu najdemo $\mathrm{v}$ znamenitih Pamukkalah v provinci Denizli v Turčiji. Opazovane oblike so nastale $\mathrm{z}$ izločanjem kalcita iz prenasičene vode $\mathrm{v}$ pogojih laminarnega toka. Oblike v velikem merilu pa nastanejo v pogojih turbulentnega toka. V članku predstavimo nekatera izhodišča, zakaj so oblike podobne kljub očitni razliki v pogojih rasti.

Klučne besede: sigove ponvice, izločanje, Škocjanske jame, Dimnice.

\section{INTRODUCTION}

Travertine terraces exhibit complex landscapes with water pools separated by networks of rimstone dams. These occur on scales of several tens to hundreds of meters. Examples are in Huanglong, Sichuan, China or in $\mathrm{Pa}-$ mukkale, Turkey. In cave passages terraces with pools up to several meters are common on sloping flowstone. On stalagmites one finds similar forms with pool dimensions of centimeters down to millimeters.

These beautiful and intricate patterns look similar, independent on their scale and result from precipita-

\footnotetext{
${ }^{1}$ Karst Processes Research Group, Institute of Experimental Physics, University of Bremen, 28359 Bremen, Germany,

e-mail: dreybrodt@ifp.uni-bremen.de

${ }^{2}$ Karst Research Institute SRC SASA, Titov trg 2, SI-6230 Postojna, e-mail: gabrovsek@zrc-sazu.si

Received/Prejeto: 25.11.2008
} 
tion of calcite from supersaturated water flowing down stream from some source.

Because of their striking geometrical properties and apparent self-similarity these features have recently attracted attempts to find models, which can reproduce such shapes. By assuming a feedback between the hydrodynamics of flow and the precipitation rates Veysey (2006), Goldenfeld et al. (2006), Chan and Goldenfeld. (2007) , Hammer et al. (2007), and Veysey and Goldenfeld (2008) presented a dynamical theories of pattern formation of rimstone terraces with statistical properties similar to those in nature. Using linear stability analysis of the underlying dynamical system Chan and Goldenfeld. (2007) showed that on inclined planes with turbulent flow a linear instability on all scales is the cause for scale invariant formation of rimstone terraces.
Fig. 1 presents an example of model comparison to a natural realm as described by Veysey (2006) and Veysey and Goldenfeld (2008). Fig. 1a shows a natural example of small terraces on the $\mathrm{cm}$-scale from Mammoth Hot springs Complex at Yellowstone National park, Wyoming, USA. The picture has been taken at a vertical distance of 2 meters. The width of the picture corresponds to $42 \mathrm{~cm}$ in nature. Fig. $1 \mathrm{~b}$ is a digitized tracing of all the dams in the photo. Fig. 1c shows one of the simulated terrace landscapes, which have been used for comparison of the statistical properties of the simulations and those of Fig. 1b.

To test these dynamic models in more detail one has to find various examples in nature, which have the same physical origin but at first glance show different characteristics.

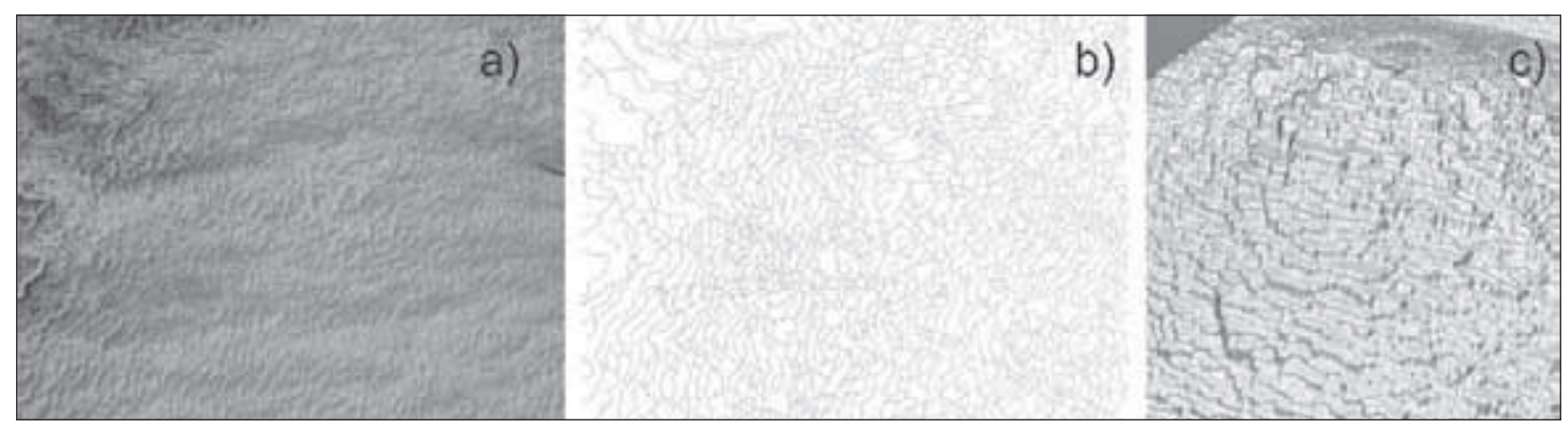

Fig. 1: a) An example of small terraces on the cm-scale from Mammoth Hot springs Complex at Yellowstone National park, Wyoming, USA. The picture has been taken at a vertical distance of 2 meters. b) Digitized trace of rimstone dams from Fig. 1a. c) The simulated terrace forms calculated for statistical comparison with the features shon in Figs. 1a and 1b. ( from Veysey (2006); see also Veysey \& Goldenfeld (2008)).

Hammer et al. (2007) reduced the complexity of the underlying differential equations by assuming that the precipitation rates are proportional to the flow velocity. This way, the flow over a given surface is first calculated and in a second step this result is used to obtain the new surface. By iteration of this procedure simulation of rimstone patterns could be obtained as they evolve in time.
In this paper we report on observations of rimstone terraces on the $\mathrm{cm}$ scale, which we have observed in two caves of Slovenia. Both have grown on stalagmite-like structures and exhibit striking differences.

\section{THE STALAGMITE IN ŠKOCJANSKE JAME (ŠKOCJAN CAVES)}

The Škocjanske jame (Škocjan Caves) developed near the contact between impermeable flysch and carbonate rocks od Kras plateau (SW Slovenia). The genesis and the present day hydrology are dominated by its allogenic recharge Reka river, which re-emerges about $35 \mathrm{~km} \mathrm{SW}$ near the Bay of Trieste. The total length of the Škocjanske jame system is $6,200 \mathrm{~m}$, while its main geomorphic feature is an underground canyon, 2,600 m long, $10-60 \mathrm{~m}$ wide, and up to $146 \mathrm{~m}$ high. The observed stalagmite grows on the left bank of the river in the middle part of the canyon called Putick's hall. The height of the ceiling above the stalagmite is about $70 \mathrm{~m}$, while the roof 


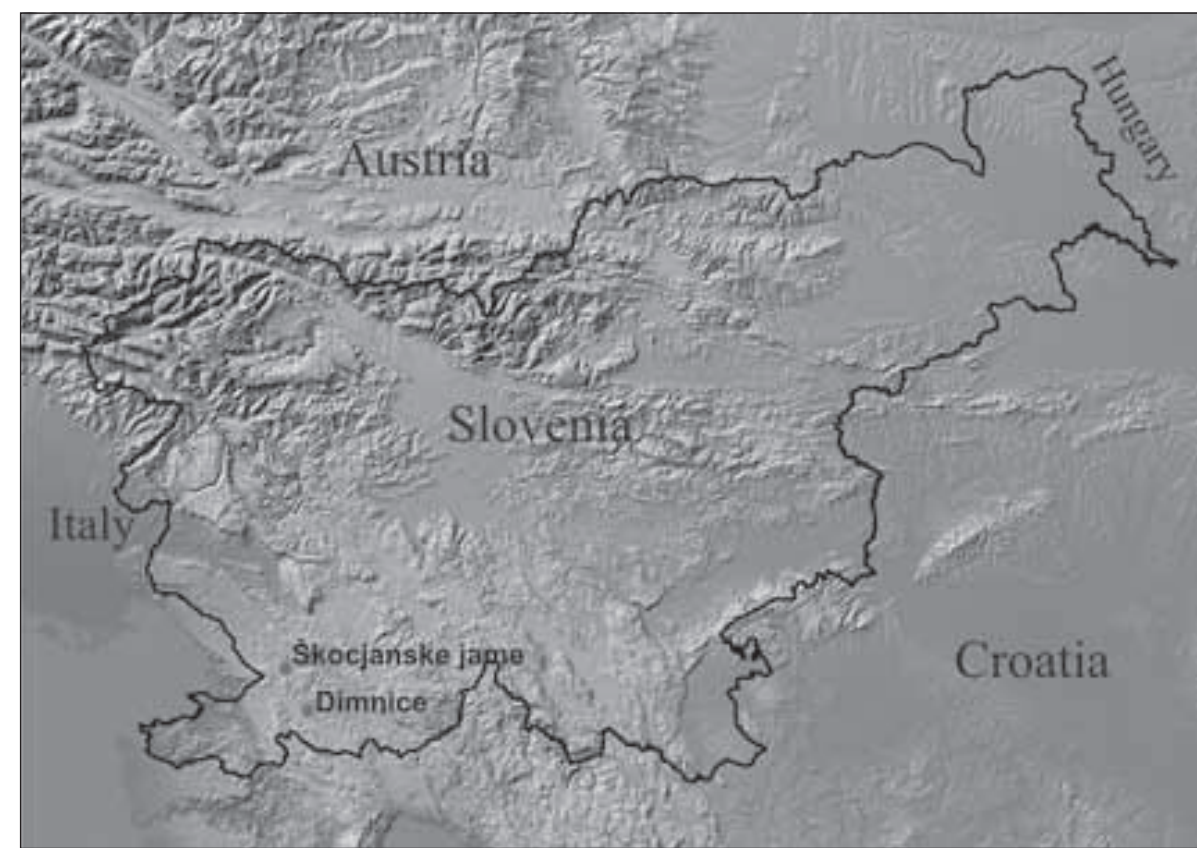

Fig. 2: Map of Slovenia with the locations of Škocjanske jame cave system and Dimnice cave.

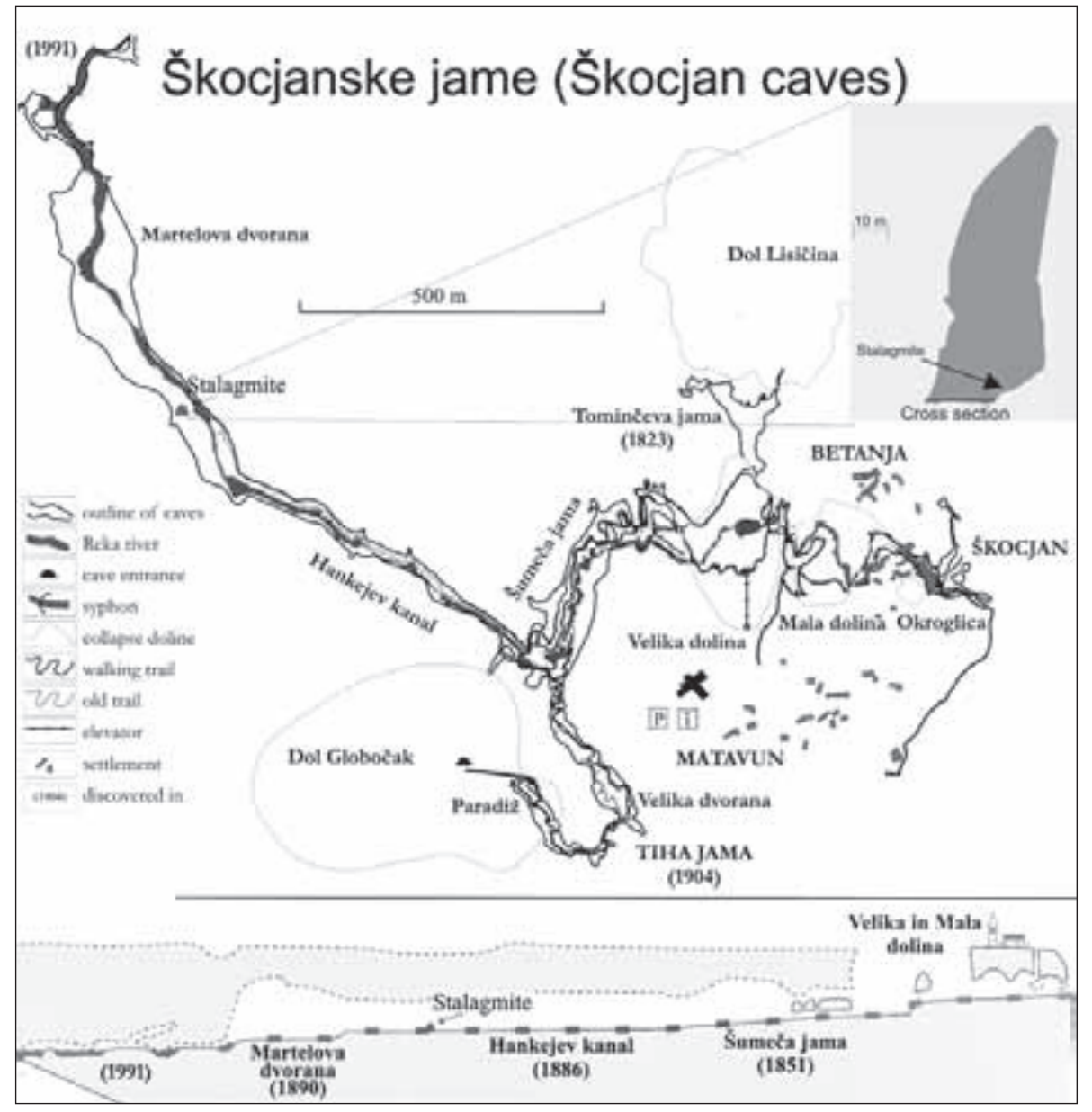

thickness is about $120 \mathrm{~m}$. The data is taken from the laser profiles recorded during the survey in 1996. The location of Škocjanske jame is shown on Fig. 2. Fig. 3 shows the generalised profile and map of the cave with the approximate position of the stalagmite. The excerpt presents the cross-section of the canyon taken at the site of the stalagmite.

Fig. 4 shows the stalagmite from the location described in Fig. 3. Its height is about $1.50 \mathrm{~m}$ and its diameter $2 \mathrm{~m}$ at its base. At the steeply inclined walls the surface shows some smooth wavy structures. But where the speleothem exhibits areas of smaller inclination, a wealth of structures appears.

The top of the stalagmite is a flat circle with about $1 \mathrm{~m}$ diameter. Fig. 5 illustrates the rich structure decorating this horizontal part of the stalagmite. Pools of various sizes, all filled with dripping water are the basic structural element. They are separated by rimstone dams. At the bottom of the pools one finds crystalline calcite particles.

At the side of the stalagmite the speleothem continues its growth as flowstone with changing slopes. At these parts rich structures are

Fig. 3: Plan and extended elevation of Škocjanske jame with the position of discussed stalagmite. The shadowed rectangular excerpt shows a cross-section of the underground canyon at the position of stalagmite. The height of the ceiling is about $70 \mathrm{~m}$, the roof thickness is $120 \mathrm{~m}$. Source: Slovenian cave cadastre. 


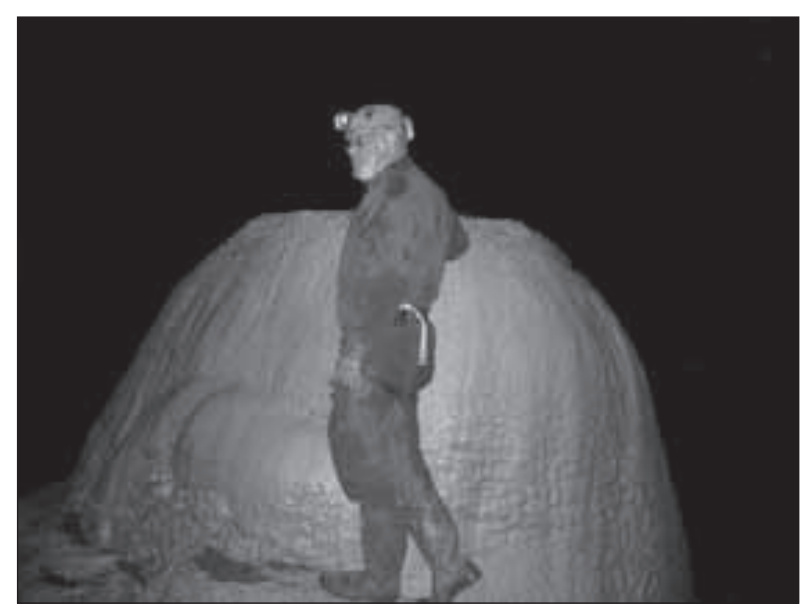

Fig. 4: The stalagmite with rimstone terraces in Škocjanske jame (gross view) (Photo: F. Gabrovšek).

dominating, as can be seen in Fig. 6, which gives views at different parts of the speleothem, all looking very similar.

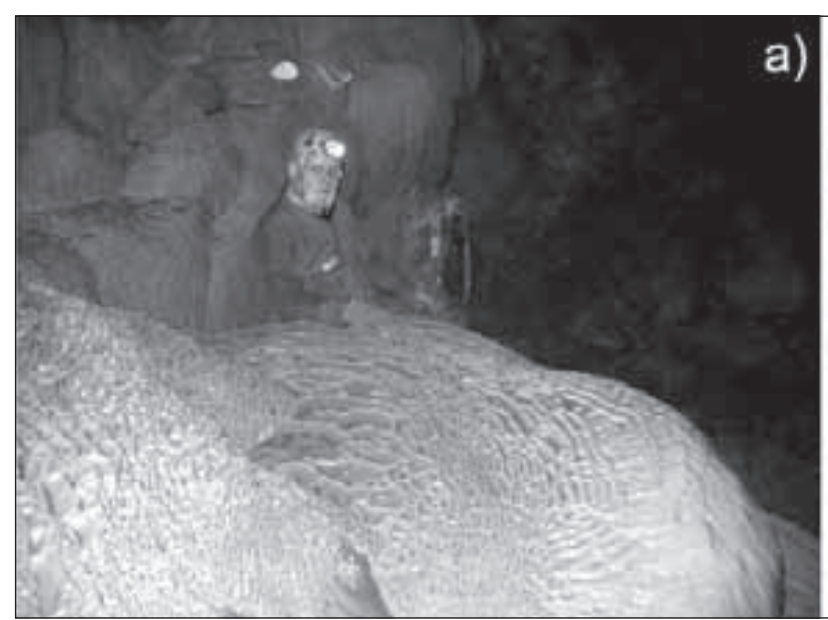

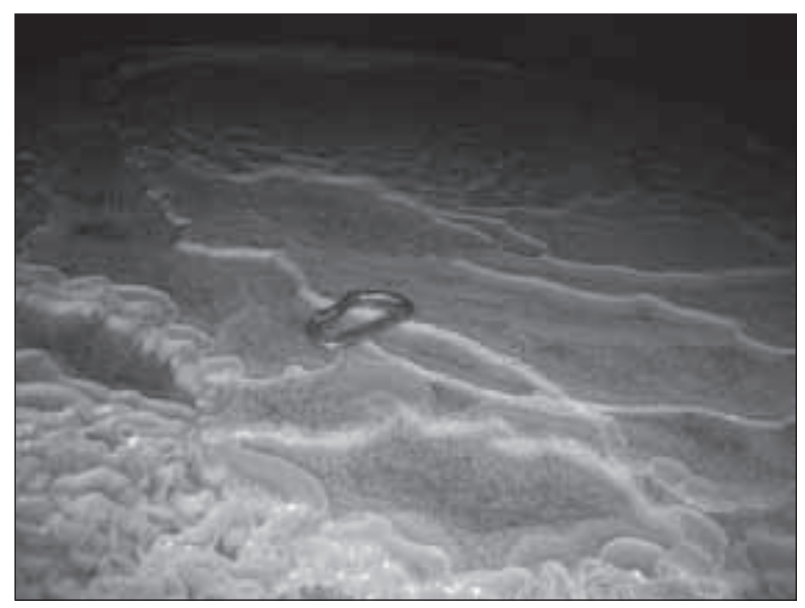

Fig. 5: Pools of various sizes, separated by rimstone dams on the top, flat part of the stalagmite (Photo: F. Gabrovšek).

A topic of future work could be an intense documentation of the statistical properties and the scales of such features and to measure the corresponding slopes,

Fig. 6: Different views of the stalagmite presenting the change of the structure at the slope transition (Photo: F. Gabrovšek).

The size of the pools depends on the slope. Structures become smaller with increasing slope.

This is clearly demonstrated in Fig. 6, which gives a closer view to the terrace forms. A flat structure of large elongated rimstone pools with average length of about $8 \mathrm{~cm}$ and an average width of $2 \mathrm{~cm}$ is surrounded by steeply sloping walls. These also exhibit rimstone structures of smaller pools of about $1 \mathrm{~cm}$ width. From these observations one could speculate that the slope of the underlying surface controls the size and the shape of the rimstone dams.

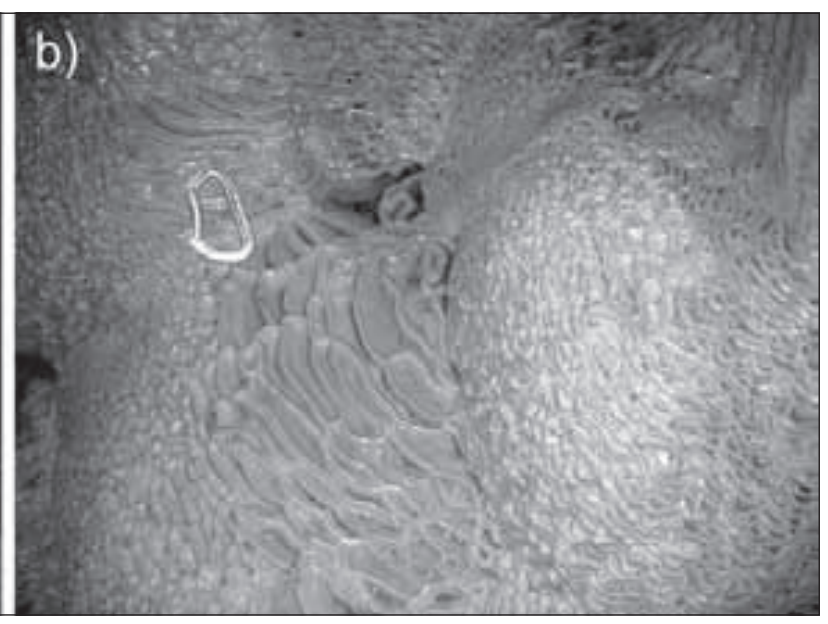

to see whether some correlation can be found. For modellers such in situ observations, especially in caves, where no outside disturbance is active, could be of high interest. The scarceness of such information in the literature prompted us to carry this study in order to draw the attention of modelers to the importance of in-situ observations. 


\section{ISOLATED RIMESTONE DAMS IN THE CAVE DIMMICE, SLOVENIA}

The cave Dimnice located in SW Slovenia is about $8 \mathrm{~km}$ long and almost $180 \mathrm{~m}$ deep (Fig. 2). It belongs to the contact karst of Matarsko podolje, where the series of blind valleys evolved along the flysch - limestone contact. The cave has two entrances, both shafts of about

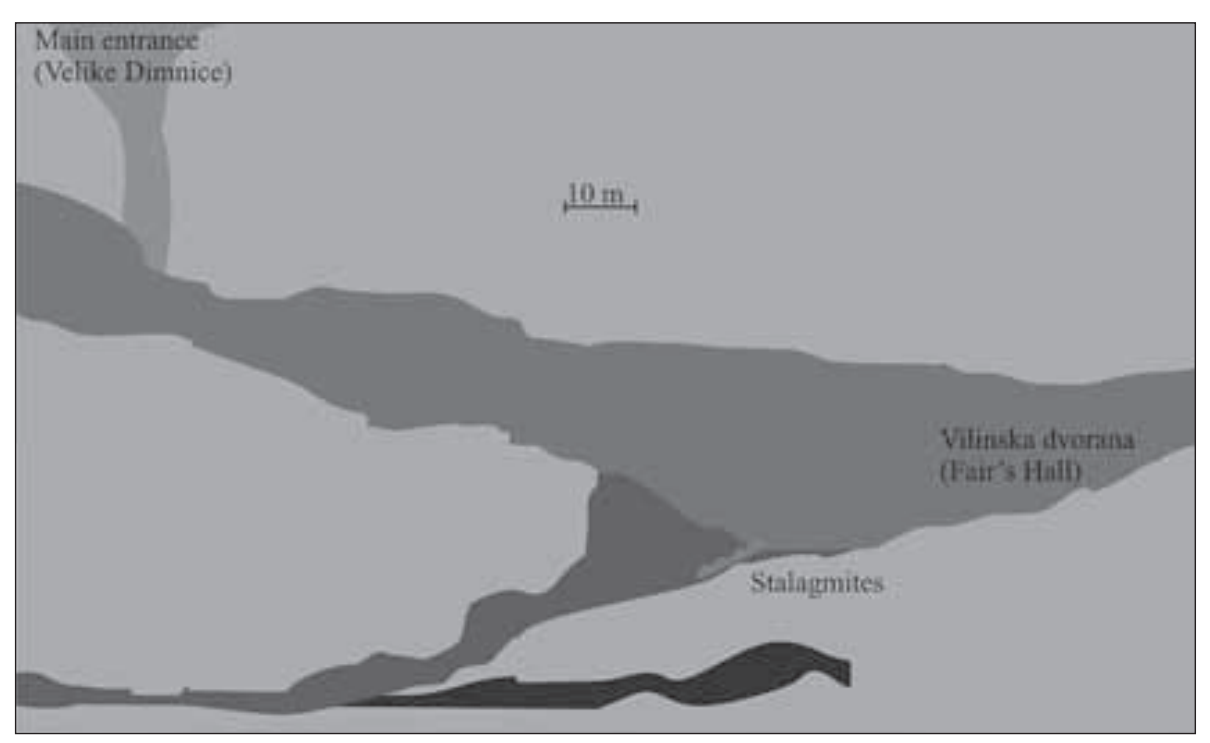

Fig. 7: Extended elevation of the part of Dimnice with the position of speleothems discussed in the text. (Remake from the original plan in Slovene cave cadastre).

$40 \mathrm{~m}$ depth. These are connected with a series of large, well decorated dry galleries. The deeper parts of the cave close to the main entrance. Fig. 7 depicts the details. On the slope consisting mostly of loose gravel some unique speleothems are found. A series of globular mounds about $1 \mathrm{~m}$ in height exhibit active growth with water supply from the cave roof about 20-25 meters high (the data is taken from the cave map in Slovene cave cadastre). The upper parts are covered by caps of white calcite, which show dentritic structures. These features are illustrated in Fig. 8.

Basically the structure is stalagmite-like with diameters of several ten centimetres. Such radii can grow only with a feed rate of about 10 drops per minute to the apex of the stalagmite (Dreybrodt 1988, 1999; Romanov et al. 2008a, b). When we visited the cave a thin layer of water covered the speloethems.

Much more interesting features are growing below the white caps of calcite at the top. Fig. 9 illustrates step like structures at the steep side, which consist of various small pools filled with water.
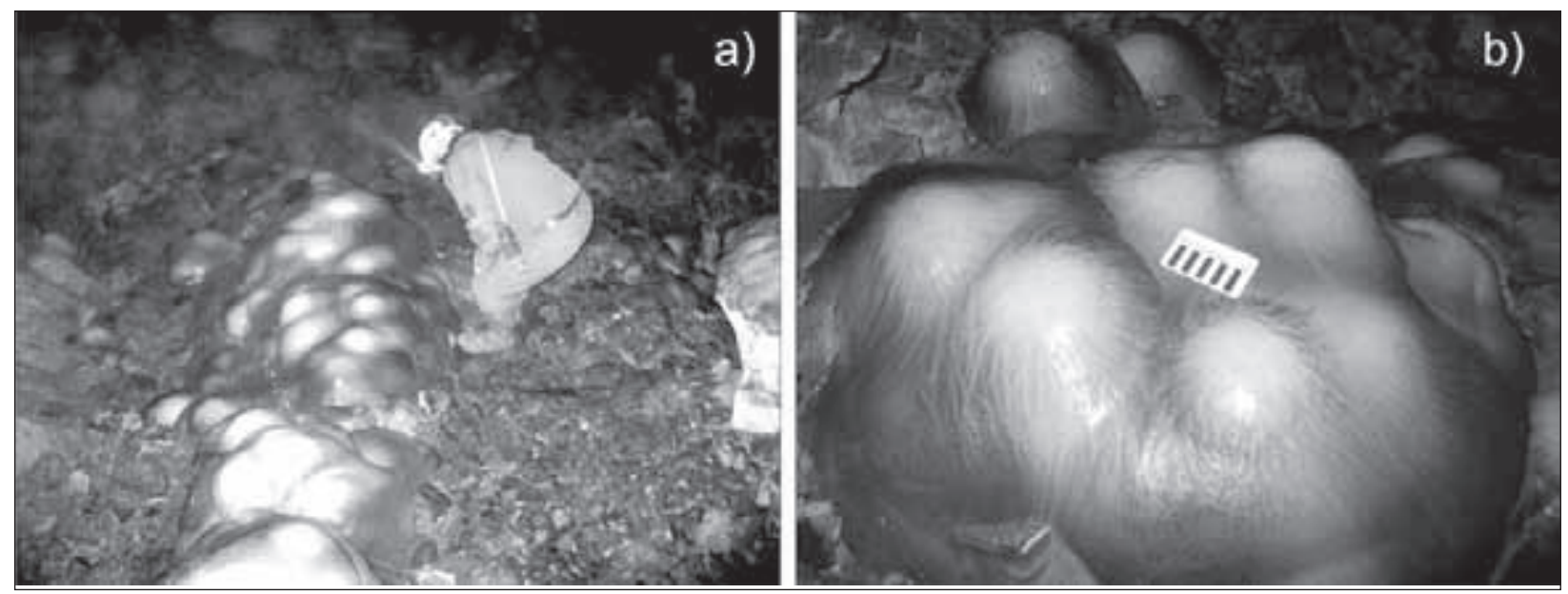

Fig. 8 : A series of globular mounds in Dimnice cave. a) The position of speleothems on the gravel slope. b) Detail (Photo: F. Gabrovšek).

consist of smaller stream passages. Water in the cave originates from the nearby sinking stream. The observed speleothems are located in Vilinska dvorana (Fair's Hall)
Fig. 10a gives a view from the top of the stalagmite. Various rimstone dams of rectangular or polygon shape, with almost straight walls are seen. A close up view of 


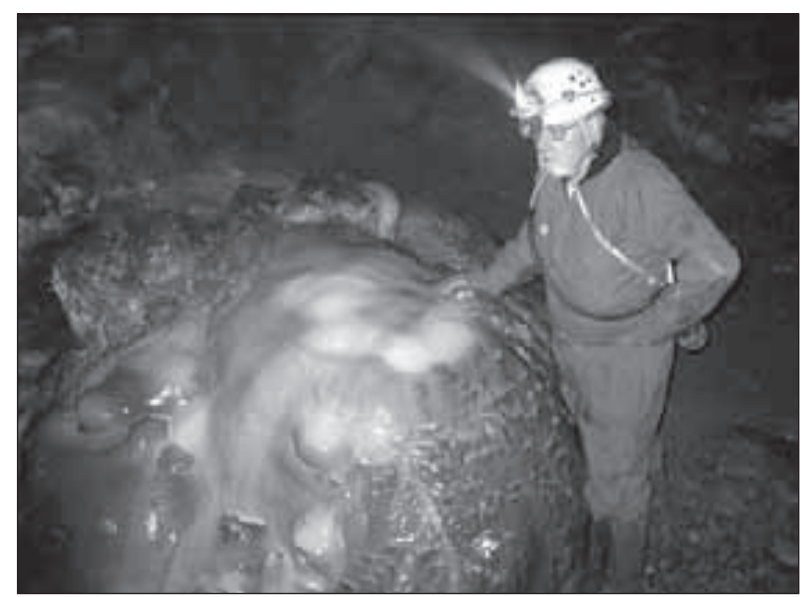

Fig. 9: Step-like structures at the steep side consisting of various small basins filled with water (Photo: F. Gabrovšek).

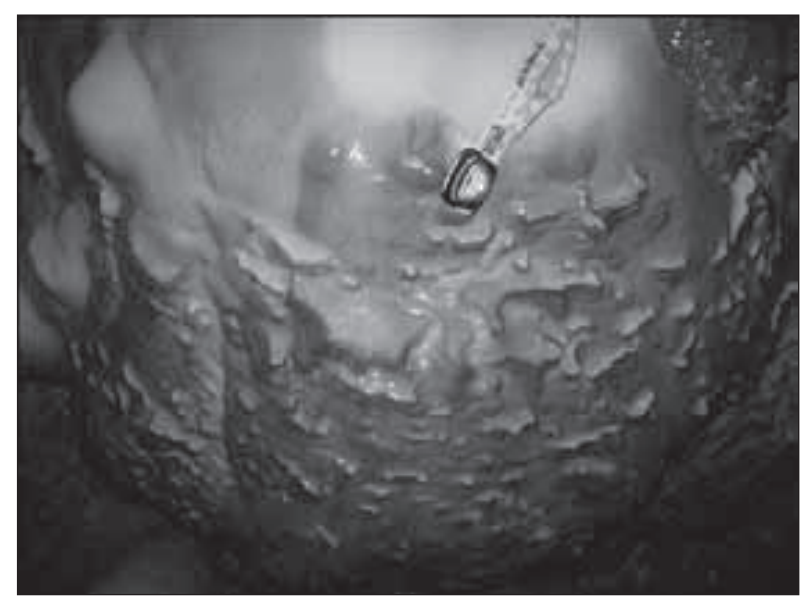

Fig. 11: Vertical distribution of rimstone pools the shape and size of the pools changes with increasing slope (Photo: F. Gabrovšek).
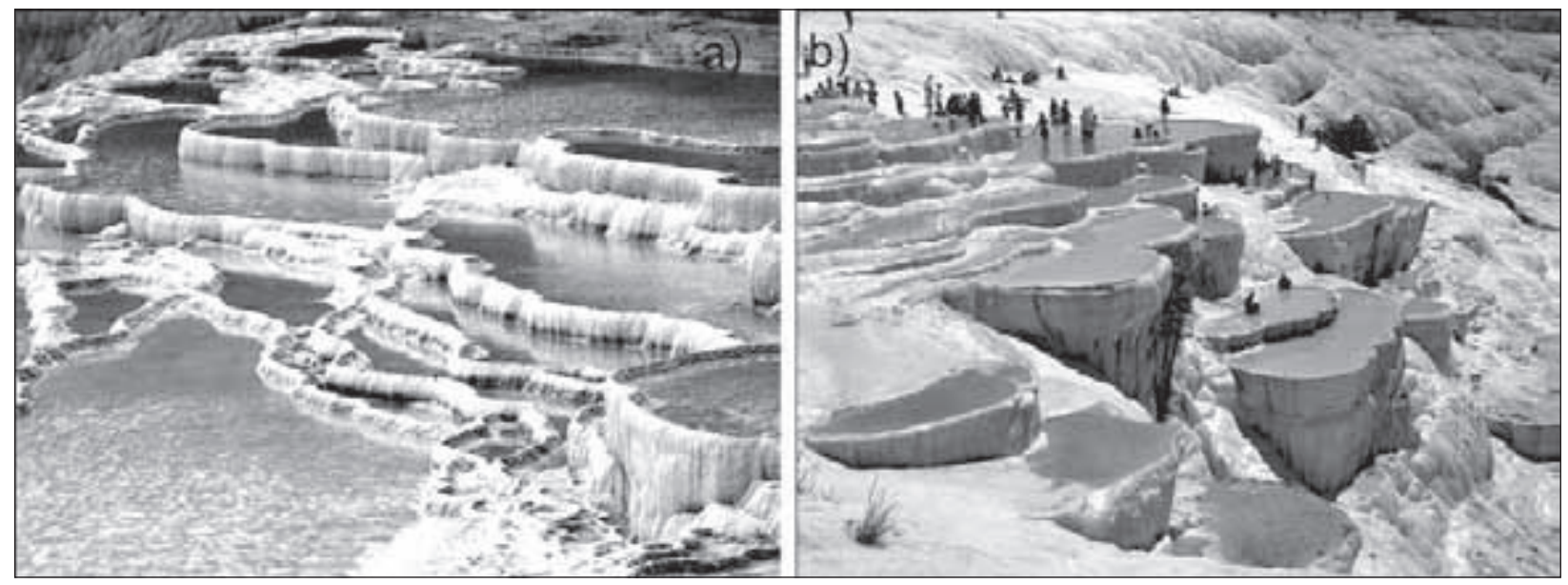

Fig. 12: a) Rimstone dams at Pamukkale, Turkey. b) Patterns similar as in Dimnice cave occur on large scales as isolated ponds at Pamukkale (Photo: F. Gabrovšek).
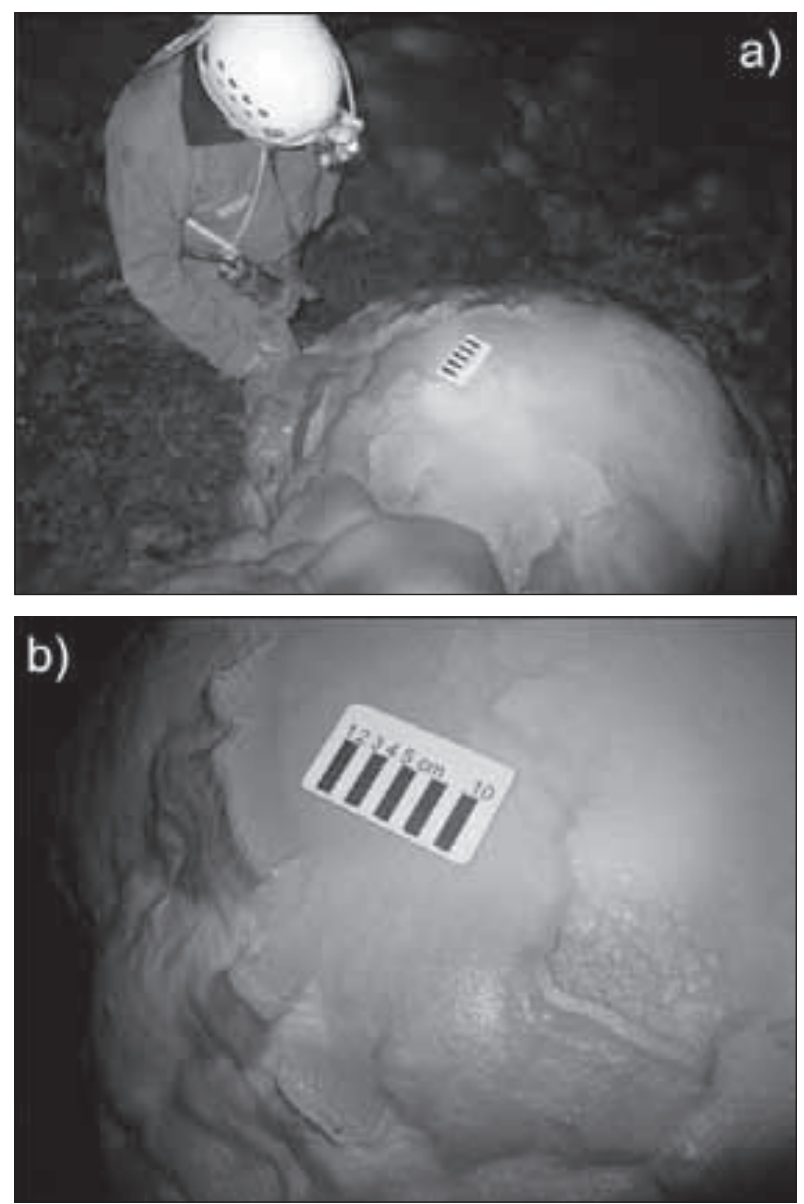

Fig.10: a) Top view of the stalagmite. b) A close up view of some isolated basins (Photo: F. Gabrovšek). 
some basins in Fig. 10a is presented in Fig. 10b. All rimstone dams, some with rectangular shape are isolated and do not touch each other. At the time of our visits they were were filled with water. The bottom of these pools is covered by calcite crystals with a diameter of a few millimeters. The widths of the dams are in the order of about ten centimeters.
As shown in Fig. 11, larger dams are only located where the slope is still moderate. Further down, where the walls of speleothem become steeper, the features become smaller and also attain triangular shapes.

\section{DISCUSSION}

We have presented two distinctly different landscape patterns of rimstone dams on speleothems on the scale of centimetres. Both may have in common that most likely they originated at low water supply of dripping waters from the roof of the cave. As a consequence, flow was laminar everywhere. Nevertheless the rimstone patterns at the base of the stalagmite in Škocjanske jame (Figs. 46) are strikingly similar to large-scale patterns (Fig. 12), when large amounts of water generate turbulent flow over the lips of the dams. Fig. 13a shows such a structure of rimstone dams on Pamukkale, Turkey. Patterns, similar to those observed in Dimnice, occur on large scales as isolated ponds at Pamukkale (Fig. 12b).

When modelling terrace structures various assumptions were considered:

a) Hammer et al. (2007) and Chan and Goldenfeld (2007) considered the growth of terraces under turbulent flow and assumed that the deposition rates depend only on the velocity of flow.

b) Deposition rates are independent of the distance from the water source to the local position. In other words, the amount of water feeding the terraced is so large that its $\mathrm{Ca}^{2+}$ concentration remains unaffected by the amount of calcite deposited on its way down.

However, models assuming growth rates, which depend on the local slope and decrease with distance from the input source (Jettestuen et al. 2006) also have been used successfully to create realistic models of rimstone dams.

The features of our observations are created in the chemical systems $\mathrm{H}_{2} \mathrm{O}-\mathrm{CaCO}_{3}-\mathrm{CO}_{2}$, where deposition rates at given chemical composition depend on the depth $h$ of the water layer covering the surface (Buhmann \& Dreybrodt 1985; Dreybrodt et al. 1997; Baker et al. 1998).

For laminar flow three regions are found:

a) At depth smaller than $0.005 \mathrm{~cm}$, the deposition rates are linearly dependent on the depth $h$, because precipitation is limited by slow conversion of $\mathrm{H}_{2} \mathrm{CO}_{3}$ to $\mathrm{CO}_{2}$. b) In the region $0.01 \mathrm{~cm}<h<0.04 \mathrm{~cm}$, rates are only weakly dependent on depth, because both $\mathrm{CO}_{2}$ conversion and diffusion control the rates.

c) For deeper water films diffusion becomes rate limiting and the rates decrease with increasing depth.

In turbulent flow diffusion is highly enhanced and is no longer rate limiting. Theoretically, if turbulent flow could arise for water depth $h<0.05 \mathrm{~cm}$, rates would depend on $\mathrm{h}$ as in the case of laminar flow, because $\mathrm{CO}_{2}$ conversion solely is rate limiting (Dreybrodt \& Buhmann 1991). With increasing depth, rates increase until they reach a maximum controlled entirely by surface rates. In reality the rates are controlled by a laminar diffusion boundary layer which separates the solid surface from the turbulent core of the fluid. Nevertheless, for $\mathrm{h}>$ $0.1 \mathrm{~cm}$, the rates increase significantly with increasing depth, until $h \approx 10 \mathrm{~cm}$, when a maximum is reached (Liu \& Dreybrodt 1997).

Although from this different behaviour in laminar and turbulent flow differences of precipitation patterns should be expected, this does not seem to be the case in nature.

One way out of this problem could be to couple precipitation rates to the depth of the water, which is controlled by flow velocity. Then, the precipitation rates in both laminar and turbulent flow follow similar rules.

For laminar flow the rates increase with water depth until they reach a maximum and decline drastically for a depth of more than several millimetres in the pool. In case of the turbulent flow above the lips of the dams, the rates also increase with depth until they become constant at depths of about $10 \mathrm{~cm}$. In the pools, however, the fluid stays almost stagnant and the rates are significantly lower. This has been observed in the field by Liu et al. (1995) and Bono et al. (2001).

From this reasoning future modelling could try to couple flow and precipitation rates by a simple function of water depth, increasing linearly with depth, reaching a maximum and then declining to some lower value. 


\section{REFERENCES}

Baker, A., Genty, D., Dreybrodt, W., Barnes, W.L., Mockler, N. J. \& J. Grapes, 1998: Testing theoretically predicted stalagmite growth rate with Recent annually laminated samples: Implications for past stalagmite deposition.- Geochim. Cosmochim. Acta, 62, 393404.

Bono, P., Dreybrodt, W., Ercole, S., Percopo, C. \& K. Vosbeck, 2001: Inorganic calcite precipitation in Tartare karstic spring (Lazio, central Italy): Field measurements and theoretical prediction on depositional rates.- Environmental Geology, 41, 305-313.

Buhmann, D., \& W. Dreybrodt, 1985: The kinetics of calcite dissolution and precipitation in geologically relevant situations of karst areas: 1. Open system.Chemical Geology, 48, 189-211.

Chan, P.Y. \& N. Goldenfeld, 2007: Steady states and linear stability analysis of precipitation pattern formation at geothermal hot springs.- Physical Review E 76, 046104 (1-11).

Dreybrodt, W., 1988: Processes in Karst Systems - Physics, Chemistry and Geology.- Springer, Berlin \& New York.

Dreybrodt, W., 1999: Chemical kinetics, speleothem growth and climate.- Boreas, 28, 347-356.

Dreybrodt, W. \& D. Buhmann, 1991: A mass transfer model for dissolution and precipitation of calcite from solutions in turbulent motion.- Chem. Geol., 90, 107-122.

Dreybrodt, W., Eisenlohr, L., Madry, B. \& S. Ringer, 1997: Precipitation kinetics of calcite in the system $\mathrm{CaCO}_{3}$ $-\mathrm{H}_{2} \mathrm{O}-\mathrm{CO}_{2}$ : The conversion to $\mathrm{CO}_{2}$ by the slow process $\mathrm{H}^{+}+\mathrm{HCO}_{3}^{-} \rightarrow \mathrm{CO}_{2}+\mathrm{H}_{2} \mathrm{O}$ as a rate limiting step.- Geochim. Cosmochim. Acta, 60, 3897-3904.

Goldenfeld, N., Chan, P. Y., \& J. Veysey, 2006: Dynamics of Precipitation Pattern Formation at Geothermal Hot Springs.- Phys. Rev. Letters, 24501-1-4.
Hammer, Ø., Dysthe, D.K. \& B. Jamtveit, 2007: The dynamics of travertine dams.- Earth and Planetary Science Letters, 256, 258-263.

Jettestuen, E., Jamtveit, B., Podladchikov, Y.Y., deVilliers, S., Amundsen, H.E.F. \& P. Meakin, 2006: Growth and characterization of complex mineral surfaces.Earth and Planetary Science Letters, 249, 108-118.

Liu, Z., Svensson, U., Dreybrodt, W., Daoxian, Y. \& D. Buhmann, 1995: Hydrodynamic control of inorganic calcite precipitation in Huanglong Ravine, China: Field measurements and theoretical prediction of deposition rates.- Geochim. Cosmochim. Acta, 59, 3087-3097.

Liu, Z. H. \& W. Dreybrodt 1997: Dissolution kinetics of calcium carbonate minerals in $\mathrm{H}_{2} \mathrm{O} \mathrm{CO}$ solutions in turbulent flow: The role of the diffusion boundary layer and the slow reaction $\mathrm{H}_{2} \mathrm{O}^{+} \mathrm{CO}_{2}$ reversible arrow $\mathrm{H}^{+}+\mathrm{HCO}_{3}$.- Geochimica et cosmochimica acta, 61, 2879-2889.

Romanov, D., Kaufmann, G. \& W. Dreybrodt, 2008a: Modeling stalagmite growth by first principles of chemistry and physics of calcite precipitation.Geochim. Cosmochim. Acta, 72, 423-437.

Romanov, D., Kaufmann, G. \& W. Dreybrodt, 2008b: $\delta^{13} \mathrm{C}$ profiles along growth layers of stalagmites: Comparing theoretical and experimental results.Geochim. Cosmochim. Acta, 72, 438-448.

Veysey, J.J., 2006: Complex fluid dynamics: From laminar to geophysical flows.- $\mathrm{PhD}$-thesis, University of Illinois at Urbana Champaign, Illinois.

Veysey, J. \& N. Goldenfeld, 2008: Watching rocks grow.Nature physics, 4, 310-313. 